\title{
Stable isotope compositions of the Penninic ophiolites of the Kõszeg-Rechnitz series
}

\author{
Attila Demény \\ Institute for G eochemical Research, H ungarian \\ A cademy of Sciences, Budapest
}

\author{
Torsten W. Vennemann \\ Institut de M inéralogie et Géochimie, U niversité de \\ Lausanne, Lausanne
}

\author{
Friedrich Koller \\ D epartment of G eological Sciences, \\ U niversity of Vienna, Vienna
}

The ophiolitic rocks of the easternmost Penninic unit, the Kõszeg-Rechnitz series, were analyzed for their $\mathrm{H}, \mathrm{C}$ and $\mathrm{O}$ stable isotope compositions. Serpentinite, gabbro, blueschist, talc deposits, ophicarbonates, as well as calcite and inclusion fluids from quartz segregation veins were analyzed in order to determine the effects of different metamorphic events on the stable isotope compositions.

The oxygen isotope compositions have a wide range depending on rock type and locality. Gabbro and serpentinite of Bienenhütte (Bernstein Window) have preserved mantle-like $\delta^{18} \mathrm{O}$ values (5.9 to $6.3 \%$; all values are in \%o relative to $\mathrm{V}$-SMOW), whereas the serpentinite of Glashütten and Rumpersdorf (Kõszeg-Rechnitz Window) and the silicate minerals of the ophicarbonate rocks show a strong ${ }^{18} \mathrm{O}$-enrichment (up to $16.2 \%$ ). The ${ }^{18} \mathrm{O}$-enrichment may have been induced by lowtemperature serpentinization or interaction with ${ }^{18} \mathrm{O}$-rich fluids that had been in equilibrium with sedimentary rocks. Contrary to the $\mathrm{O}$ isotope compositions, the $\mathrm{H}$ isotope compositions seem to be homogeneous in the entire series, with $D$ values of $-63 \pm 7 \%$ o. Only some serpentinite rocks were depleted in D (down to $-106 \%$ ), usually regarded as a result of interaction with meteoric water infiltrating during late-stage metamorphism. The meteoric water infiltration was rather limited, as even samples taken directly from slickensides within serpentinite bodies preserved isotopic compositions close to those of the bulk series. $\mathrm{H}$ and $\mathrm{O}$ isotope compositions of fluids mobilized in the metasedimentary rocks of the Penninic unit during the main metamorphic stage were determined by analyzing inclusion fluids and calcites in quartz-carbonate veins. The isotope compositions indicate interaction between these fluids and the ophiolite series, although relative deuterium enrichment has been preserved in the ophiolitic rocks.

The strong D-enrichment characteristic for oceanic crust that has experienced high-temperature interaction with seawater was not detected. However, the $\mathrm{H}$ isotope compositions obtained for the Kõszeg-Rechnitz series indicate that subduction of the Penninic oceanic crust and the associated devolatilization may have been potentially responsible for mantle metasomatism, resulting in $\mathrm{H}$

Addresses: A. Demény: H-1112 Budapest, Budaörsi út 45, Hungary, e-mail: demeny@geochem.hu T. W. Vennemann: L'Anthropole, CH-1015 Lausanne, Switzerland F. Koller: Althanstr. 14, 1090 Vienna, Austria

Received: January 2, 2007, accepted: March 28, 2007 
30 A. Demény et al.

isotope compositions of about $-40 \%$, similar to the range determined from mantle-derived amphibole megacrysts (Demény et al. 2005). To conclude, the present dataset is discussed in the light of earlier studies on the formation of the Sopron leucophyllite.

Key words: Kõszeg-Rechnitz Penninic unit, ophiolites, stable isotope compositions

\section{Introduction}

Metasomatic events related to devolatilization of oceanic crust material have been described in several magmatic and metamorphic complexes of the Carpathian-Pannonian Region. Formation of glass pockets and carbonatebearing silicate glass veins in peridotite xenoliths has been attributed to the infiltration of fluids/melts released from subducted oceanic crust (Szabó et al. 1996; Bali et al. 2002; Demény et al. 2004). Geochemical, radiogenic and stable isotope compositions of alkaline basalts and andesitic complexes al so indicate the effect of subducted material, although the relative importance of melt or fluid has not been exactly determined. One of the most important candidates for subducted material is the Penninic oceanic crust, the subduction of which began in the Cretaceous. One of the most intriguing examples of metasomatism related to devolatilization of oceanic crust material is the formation of leucophyllite of the Sopron metamorphic complex, the stable isotope characteristics of which suggest a reaction with fluids released from serpentinite (Demény et al. 1997). However, the source of such fluids, and whether or not they are truly related to subduction of oceanic crust relics such as those of the Penninic unit of the Kõszeg-Rechnitz series, remains undetermined to date. The aim of this study is to evaluate whether the oceanic crust relics of the Kõszeg-Rechnitz Penninic system were the sources of the fluids, and to compare these with those responsible for metasomatism of the metamorphic and magmatic rocks of the Carpathian-Pannonian region. The resolution of this question has important consequences for the reconstructions of the tectonic evolution of this part of the Carpathian-Pannonian region.

\section{Geologic background and samples}

The Penninic unit of the Eastern Alps crops out below Austroal pine nappes in four tectonic windows, the Möltern, the Bernstein, the Kõszeg-Rechnitz and the Vashegy-Eisenberg windows (from north to south, Fig. 1). The Penninic unit contains the Bündnerschiefer series, consisting of phyllite, calcareous phyllite, quartzite and metaconglomerate, and a greenschist-dominated ophiolite complex with ultramafic bodies and gabbro (Koller and Pahr 1980). Plagiogranite, rodingite and ophicarbonates occur sporadically within this complex. The ultramafic bodies are strongly serpentinized; magmatic relics survived in the gabbroic rocks only (Koller 1985). The Penninic unit is strongly folded and consists of several internal nappes (Ratschbacher et al. 1990; Dudko and Younes 


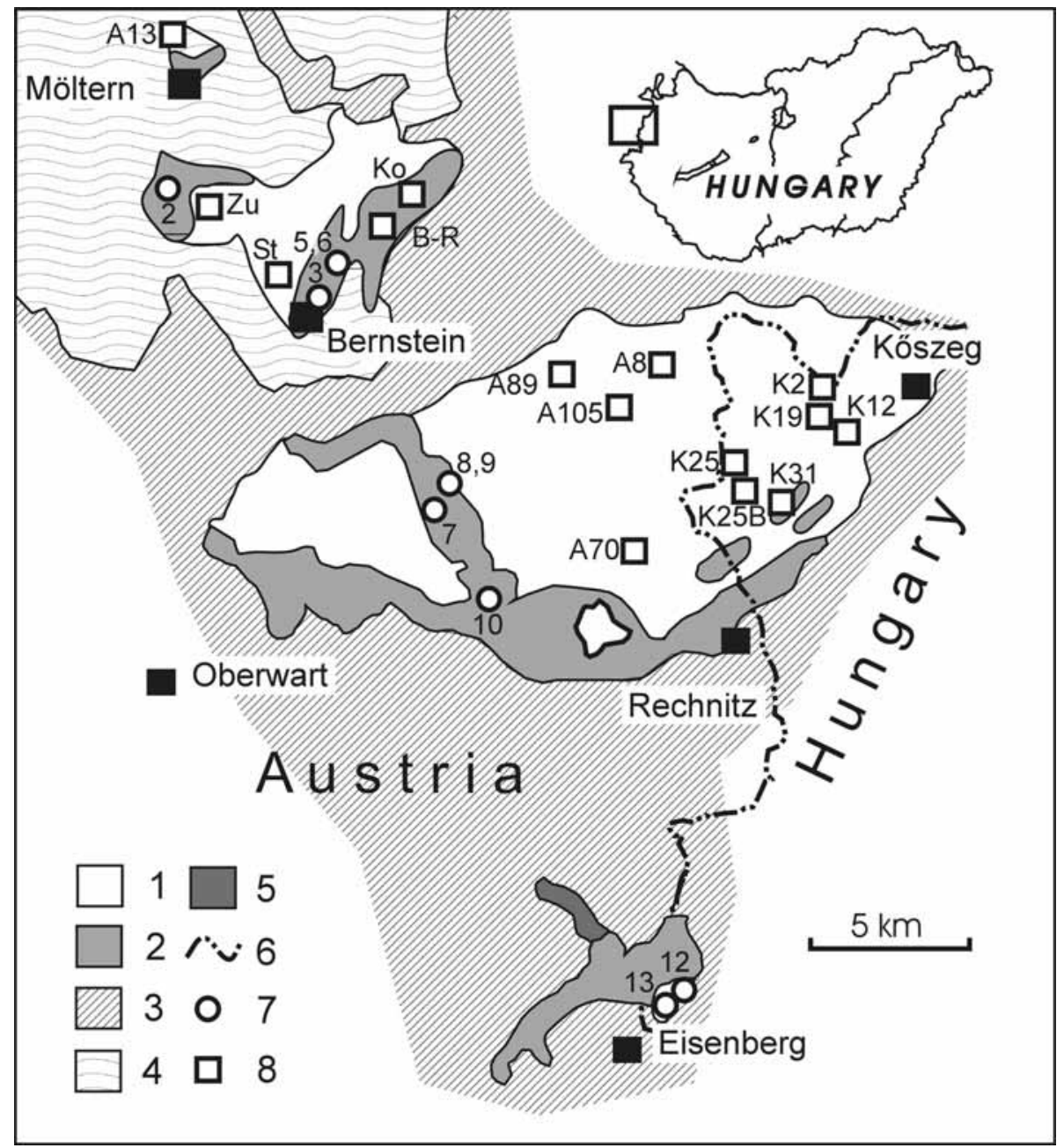

Fig. 1

Penninic windows at the eastern end of the Alps (Western Hungary and Eastern Austria) and sample localities. 1. Penninic metasediments, 2. Penninic ophiolitic rocks, 3. lower Austroal pine rocks, 4. upper Austroal pine rocks, 5. Tertiary sediments, 6. boundary, 7. samples from ophiolitic rocks (all samples marked "PEN" in Tables 1 and 2), 8. quartz veins from metasedimentary rocks (all samples marked "Q 06" in Table 2)

1990; Wiedemann and Younes 1990; Neubauer et al. 1992). The rocks were exhumed during Middle Miocene crustal extension (Tari and Bally 1990; Dunkl and Demény 1997). The metamorphic evolution can be divided into three major events. The conditions of the metamorphic events recorded in the Rechnitz series are as follows (after Koller 1985): 
1. Oceanic hydrothermal activity, forming barroisite, pargasite and Mg-hornblende and causing locally high oxidation states (Koller 1985) at temperatures higher than $700{ }^{\circ} \mathrm{C}$.

2. Subduction-related HP/LT metamorphism (Lelkes-Felvári 1982) evidenced by ferroglaucophane relics in ferropargasite porphyroblasts. Other minerals include Mg-rich pumpellyite, alkalipyroxene ( Ac63)d21), lawsonite (form relics) and stilpnomelane, indicating temperatures between 330 to $370{ }^{\circ} \mathrm{C}$ and pressures of 6-8 kbars (Koller 1985).

3. Late Alpine greenschist facies metamorphism. Based on the $b_{0}$ values of white micas from metapelites it can be classified in the range of intermediate pressure metamorphism (Lelkes-Felvári 1982). Characteristic minerals include actinolite, alkalipyroxene $(\sim A c 85 \mathrm{~J}<<5)$, riebeckite or Mg-riebeckite (Kubovics 1983; Koller 1985). T values between $350-430{ }^{\circ} \mathrm{C}$, and $\mathrm{p}<3 \mathrm{kbar}$ were obtained for this metamorphism. The metamorphic grade increases from north to south, as recorded by mineral assemblages (Koller 1985) and calcite-graphite carbon isotope fractionations (Demény 1990).

The magmatic relics as well as the bulk geochemical compositions indicate that the ophiolite sequence contained N-MORB-type basalts (Koller 1985) and harzburgite bodies originated from the suboceanic mantle (Meisel et al. 1997; Melcher et al. 2002). Gabbro bodies with different chemical compositions (Fe-, Tiand Mg-rich) have also been distinguished (Koller 1985). It thus appears that the geochemical compositions have been preserved despite the subsequent metamorphism.

In this study serpentinite occurrences were sampled at different localities spanning the entire series (see sample numbers and localities in Table 1). Beside massive serpentinite, other rock types were also collected (see Table 1). The serpentinite body of Bienenhütte contains rodingite formed by metasomatic alteration of gabbro dikes and relics of serpentinized harzburgite. A chloritite rim developed around the rodingite was also sampled. Gabbro was also sampled at a number of localities. Ophicarbonates were collected from several outcrops at Glashütten near Schlaining.

In order to study the interaction between the magmatic and sedimentary complexes and infiltrating fluids, quartz veins were also collected from the metasediments of the Möltern, Bernstein and Kõszeg-Rechnitz Windows. The metasedimentary rocks whose stable isotopic compositions (see Demény 1990) are discussed in this paper are graphitic calcphyllite and marble samples with varying amounts of carbonates and silicates. The detailed petrographic description of the metasedimentary rocks was given by Demény (1990). The quartz veins contained calcite intergrown with the quartz; thus, their respective formations are regarded as contemporaneous. The quartz veins contain several generations of fluid inclusions. The first generation is represented by scattered inclusions that generally suffered decrepitation (Fig. 2A). The second generation is represented by inclusions of negative crystal forms (Fig. 2B) scattered 
Table 1

Water contents (in wt\%) and stable $\mathrm{H}$ and $\mathrm{O}$ isotope compositions (in \%o relative to V-SMOW) of silicate rocks and mineral separates from the Penninic ophiolites of the Kõszeg-Rechnitz series

\begin{tabular}{|l|l|l|l|}
\hline & $\mathrm{H}_{2} \mathrm{O} \%$ & $\delta \mathrm{D}$ & $\delta^{18} \mathrm{O}$ \\
\hline PEN-2 mafic whole rock, Hochneukirchen & 4.53 & -65 & 16.2 \\
PEN-3/1 rodingite, Bienenhütte & 4.60 & -55 & 5.9 \\
PEN-3/2 chloritite, Bienenhütte & 13.61 & -59 & 6.8 \\
PEN-3/3 serpentinite, Bienenhütte & 13.72 & -106 & 7.4 \\
PEN-3/4 serpentized harzburgite, Bienenhütte & 13.36 & -64 & 6.3 \\
PEN-3/5 tremolite vein, Böhm quarry Kirschlag & 2.79 & -68 & 6.5 \\
PEN-5 amphibole, Schirnitz, high-Mg gabbro & 1.30 & -64 & 5.1 \\
PEN-6 blue amphibole, Schirnitz, high-Fe gabbro & 4.72 & -75 & 7.4 \\
PEN-7/1 blue amphibole, Unterkohlstatten & 2.47 & -79 & 15.5 \\
PEN-7/2 whole rock, Unterkohlstatten & 2.33 & -80 & 14.4 \\
PEN-8/1 chlorite, ophicalcite, Glasshütten b. Sch. & 10.45 & -64 & 14.2 \\
PEN-8/2 blue amphibole, ophicalcite, Glasshütten b. Sch. & 3.65 & -71 & 16.2 \\
PEN-8/4 blue amphibole, ophicalcite, Glasshütten b. Sch. & & & 15.3 \\
PEN-8/4 chlorite, ophicalcite, Glasshütten b. Sch. & 3.32 & -65 & 15.5 \\
PEN-8/5 chlorite, ophicalcite, Glasshütten b. Sch. & 1.47 & -46 & 12.2 \\
PEN-8/6 talc, ophicalcite, Glasshütten b. Sch. & 3.24 & -60 & 16.2 \\
PEN-8/7 talc, ophicalcite, Glasshütten b. Sch. & 2.61 & -67 & 15.0 \\
PEN-8/8 talc, ophicalcite, Glasshütten b. Sch. & 3.09 & -61 & 15.4 \\
PEN-9/1 serpentinite, Glasshütten b. Sch. & 13.60 & -64 & 11.8 \\
PEN-9/2 tremolite, Glasshütten b. Sch. & 3.13 & -74 & 12.1 \\
PEN-9/3 serpentinite, Glasshütten b. Sch. & 13.01 & -75 & 12.3 \\
PEN-10/1 serpentinite, Rumpersdorf & 12.24 & -85 & 11.2 \\
PEN-10/2 serpentinite, Rumpersdorf & 13.02 & -64 & 11.5 \\
PEN-12 talc, Felsőcsatár & 5.65 & -63 & 16.4 \\
PEN-13 serpentinite, Felsöcsatár & 12.80 & -61 & 13.1 \\
PEN-13 talc, Felsőcsatár & 4.71 & -58 & 14.9 \\
\hline
\end{tabular}

randomly, or formed in planes parallel with deformation lamellae or growth zones within the quartz. Thus, the formation of these inclusions can be attributed to the main metamorphic-deformation event. Thethird generation is represented by very small inclusions forming trails (Fig. $2 \mathrm{C}$ ). Liquid $\mathrm{CO}_{2}$ can be observed in the older inclusion generations (Fig. 2D).

\section{Analytical methods}

$\mathrm{C}$ and $\mathrm{O}$ isotope compositions of calcites were determined at the Institute for Geochemical Research, Budapest, using a Gasbench II automatic device attached to a Thermo Finnigan delta plus XP mass spectrometer and the method described by Spötl and Vennemann (2003). The $O$ isotope compositions of silicate minerals were determined at the University of Lausanne, Switzerland using the laserbased method of Rumble and Hoering (1994) and Kasemann et al. (2001). Water contents and $\mathrm{H}$ isotope compositions were determined by the TC/EA method established by Sharp et al. (2001). The raw data were corrected using the NBS-30 

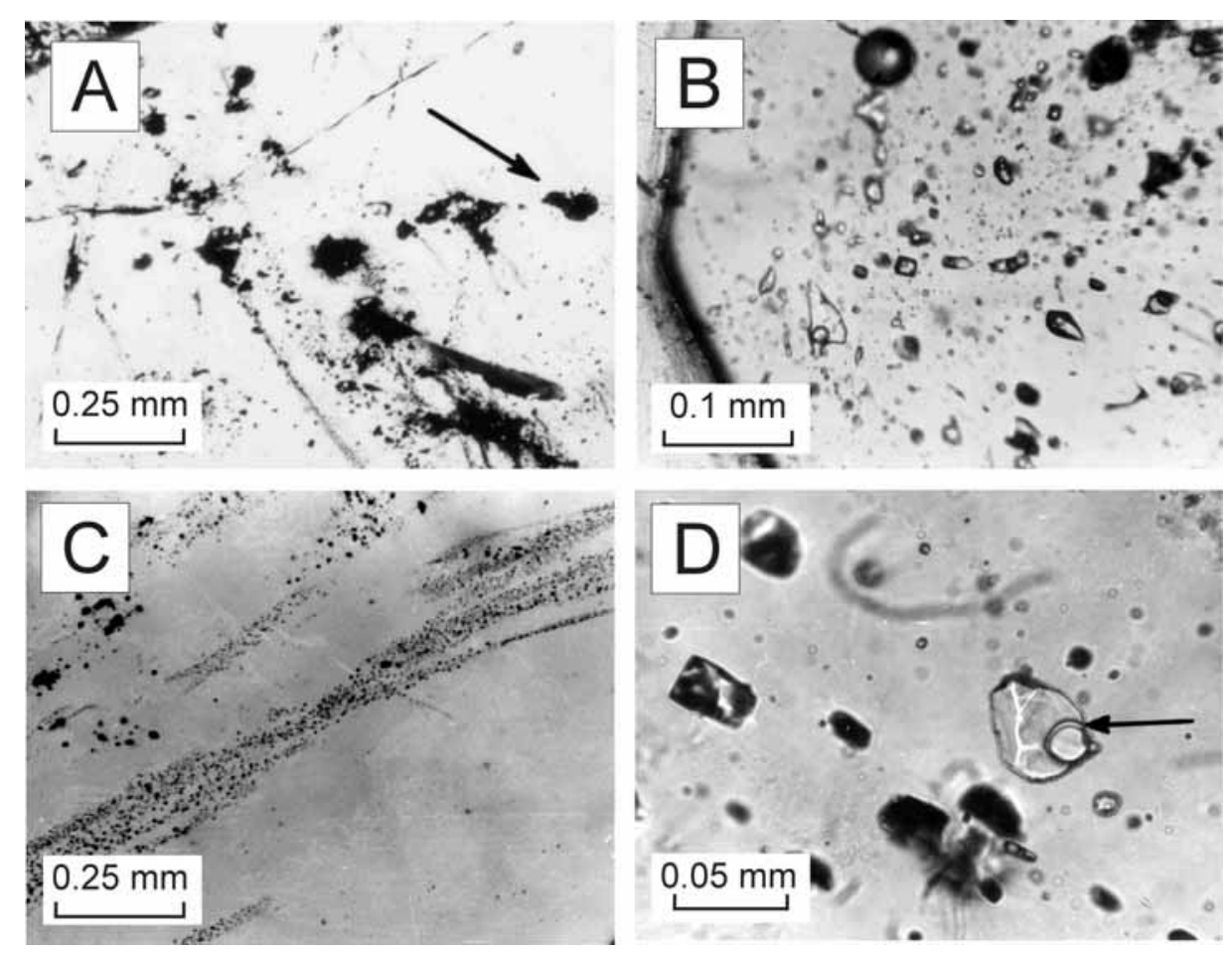

Fig. 2

Fluid inclusions in quartz veins. A. Primary, decrepitated inclusions (e.g. at arrow). B. Primary fluid inclusions in a quartz crystal. C. Trails of small inclusions formed along planes. D. Primary fluid inclusion with liquid $\mathrm{CO}_{2}$ (at arrow)

biotite standard and two laboratory standards (kaol\#17 kaolinite and G1 biotite). Inclusion fluids were released from quartz veins by thermal decrepitation under vacuum at $900{ }^{\circ} \mathrm{C}$. The $\mathrm{H}_{2} \mathrm{O}$ released was collected and purified by conventional vacuum distillation, and reacted with $\mathrm{Zn}$ alloy (from Bloomington, Indiana, U.S.A.) at $480{ }^{\circ} \mathrm{C}$ for 30 minutes. The $\mathrm{D} / \mathrm{H}$ ratio of the $\mathrm{H}_{2}$ gas produced in the reaction was determined with the Thermo Finnigan delta plus XP mass spectrometer at the Institute of Geochemical Research.

The isotope compositions are expressed in the $\delta$-notation $\left(\delta=\left(R_{1} / R_{2}-1\right) \cdot 1000\right.$ where $R_{1}$ and $R_{2}$ are the $D / H,{ }^{13} C /{ }^{12} C$ and ${ }^{18} \mathrm{O} /{ }^{16} \mathrm{O}$ ratios in the sample and the standard, respectively) in permil (\%o) relative to V-SMOW (H and O) or V-PDB (C). The analytical precision of carbonate measurements based on isotopic compositions and reproducibilities obtained on samples and standards (NBS-19 reference material and laboratory standards) is better then $0.2 \%$ for the $\mathrm{C}$ and $\mathrm{O}$ isotope values. The following $\delta^{18} \mathrm{O}$ values were obtained for international standards in the course of the study: NBS-28 quartz $9.66 \pm 0.05 \%$ o $(n=10$; theoretical value: $9.58 \%$ o), NBS-30 biotite $5.12 \pm 0.08 \%$ o $(n=4$; theoretical value: 
$5.1 \%$ ), UWG-2 garnet $5.88 \pm 0.13 \%$ o ( $n=20$; theoretical value: $5.8 \%$, Valley et al. 1995). Based on these data and the reproducibilities of duplicate data, the $\delta^{18} \mathrm{O}$ values of samples are precise within $0.15 \%$. The $\mathrm{H}$ isotope compositions of the laboratory standards obtained in this study were always within $\pm 2 \%$ o from the expected values, the reproducibilities were better then $\pm 2 \%$. The precision of $\mathrm{H}_{2} \mathrm{O}$ content measurements is better then $0.1 \mathrm{wt} \%$.

\section{Results}

The stable hydrogen isotope compositions of serpentinite, rodingite, ophicalcite, gabbro and talc deposits have a rather small range $\left(\delta D_{\text {average }}=-63\right.$ $\pm 7 \%$ o, $n=7$ ) with only two of the studied serpentinite samples being depleted in deuterium ( $D=-85$ and $-106 \%$, Table 1 ). The $\mathrm{H}_{2} \mathrm{O}$ contents of the minerals studied span a large range (Table 1), but are all in accordance with the stoichiometry of the minerals. There is only one exception (sample PEN-8/5 ophicarbonate), where separation of different silicate minerals was not possible due to the fine grain size; thus the $\mathrm{H}_{2} \mathrm{O}$ content (1.47 wt\%) was obtained from the bulk silicate fraction. Interestingly, this sample has the highest $\delta D$ value $(-46 \%)$ of the samples analyzed. In contrast to the relatively uniform $\mathrm{H}$-isotope compositions, the $\delta^{18} \mathrm{O}$ values of the silicates have a large range from 5.9 to $16.4 \%$ o (Table 1, Fig. 3), although the data reflect a systematic distribution. The rocks of the serpentinite occurrence of Bienenhütte (rodingite, chlorite-rich blackwall, serpentinized harzburgite and tremolite vein) have $\delta^{18} \mathrm{O}$ values of 5.9 to $6.8 \%$, that is close to those typical for normal mantle compositions (about 5.5\%, Mattey et al. 1994), whereas the serpentinite surrounding the rodingite has a slightly

Fig. 3

$\mathrm{H}$ and $\mathrm{O}$ isotope compositions of serpentinite and gabbro (filled circles) and silicate fractions of ophicarbonate rocks (gray filled squares) from the Penninic complex of the KõszegRechnitz series

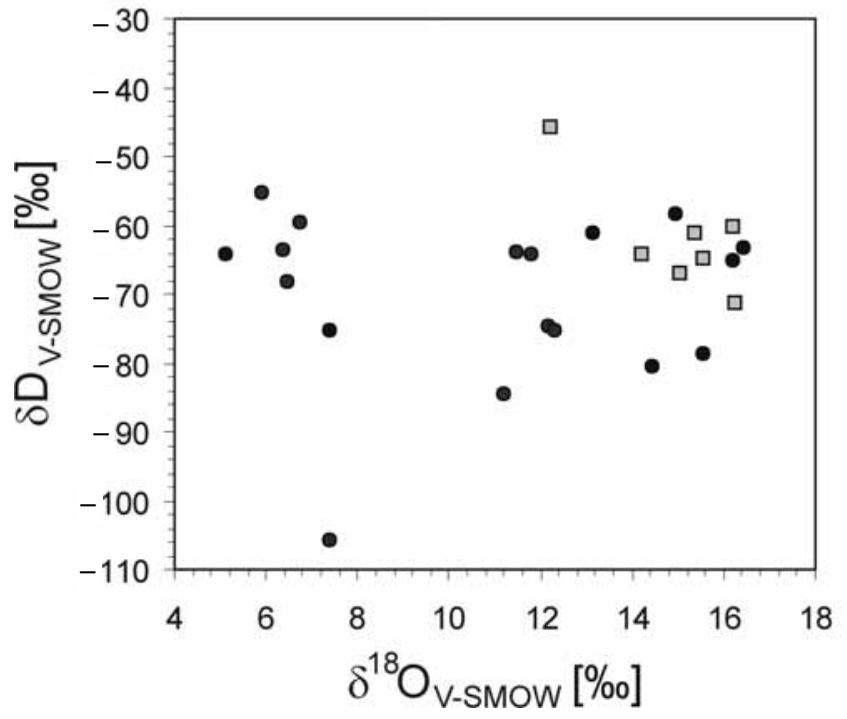

Central European Geology 50, 2007 
higher $\delta^{18} \mathrm{O}$ value (7.4\%o) and a low D value (-106\%). Chlorite, blue amphibole and talc separated from ophicalcite have $\delta^{18} \mathrm{O}$ values from 12.2 to $16.2 \%$. The matrix carbonate is also enriched in ${ }^{18} \mathrm{O}$ with $\delta^{18} \mathrm{O}$ values from 17.0 to $19.5 \%$, whereas the carbon isotope compositions range from -0.1 to $1.7 \%$ (Table 2 ). A comparison of the oxygen isotope compositions of silicate minerals and matrix calcite, shows no correlation (Fig. 4). No significant differences exist between the $\delta^{13} \mathrm{C}$ and $\delta^{18} \mathrm{O}$ values of silicate-bearing and silicate-free parts of the ophicalcite samples (Table 2).

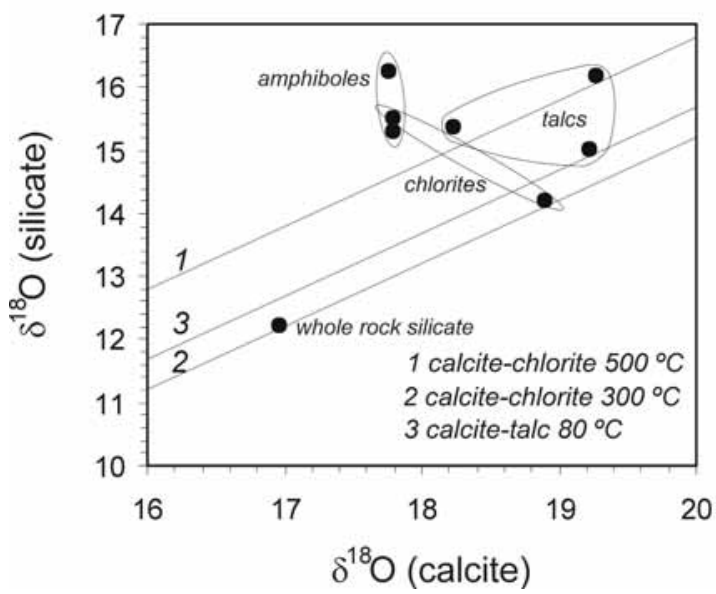

Fig. 4

$\mathrm{O}$ isotope compositions of silicate mineral separates from ophicarbonate rocks vs. matrix calcite (Penninic complex of the Kõszeg-Rechnitz series). The isotope compositions are in\%o relative to $\mathrm{V}$-SMOW. The equilibrium fractionation lines for calcite, chlorite and talc are from Zheng (1993)

In contrast to the serpentinite at Bienenhütte, that of Glashütten and Rumpersdorf has an ${ }^{18} \mathrm{O}$-enrichment similar to that observed in the ophicalcite. The talc deposit of Felsõcsatár is also characterized by relatively high $\delta^{18} \mathrm{O}$ values.

The carbon and oxygen isotope compositions of calcites measured from quartz veins (-1.3 to $1.6 \%$ ond 17.5 to $24.4 \%$, respectively) are listed in Table 2 and plotted in Fig. 5, together with the $\delta^{13} \mathrm{C}$ and $\delta^{18} \mathrm{O}$ values of the matrix carbonate of the studied sequence (Demény 1990). The vein calcite has slightly higher $\delta^{18} \mathrm{O}$ values compared to the average matrix carbonate. The $D$ values of inclusion waters in vein quartz range from -79 to $-40 \%$, with an average of $-56 \%$ (Table 2), falling in the range obtained on silicate minerals.

\section{Discussion}

Formation conditions of ophicalcite

The first question addressed in this study is to what extent the stable isotope compositions are still representative of the conditions of primary formation of the minerals. The carbon isotope compositions of the studied ophicalcite samples range from -0.1 to $1.7 \%$ indicating a normal marine origin (e.g. Hoefs 1987), in agreement with other studies on ophicarbonate rocks (Barbieri et al. 1979; Lemoine et al. 1983; Weissert and Bernoulli 1984; Früh-Green et al. 1990; Driesner 
Table 2

Stable $\mathrm{C}$ and $\mathrm{O}$ isotope compositions of carbonates and $\mathrm{H}$ isotope compositions of inclusion fluids from quartz veins of the Kõszeg-Rechnitz series. The isotope data are in \%o relative to V-PDB (C) and V-SMOW ( $\mathrm{H}$ and $\mathrm{O})$

\begin{tabular}{|c|c|c|c|c|c|c|}
\hline \multicolumn{7}{|l|}{ Ophicalcites } \\
\hline & $\delta^{13} \mathrm{C}$ & $\delta^{18} \mathrm{O}$ & & $\delta^{13} \mathrm{C}$ & \multicolumn{2}{|l|}{$\delta^{18} \mathrm{O}$} \\
\hline PEN-8/1 white & 0.3 & 19.5 & PEN-8/5 grey & 1.1 & \multicolumn{2}{|l|}{17.0} \\
\hline PEN-8/1 grey & -0.1 & 18.9 & $\mathrm{PEN}-8 / 6$ & 0.8 & \multicolumn{2}{|l|}{19.4} \\
\hline PEN-8/2 white & 1.3 & 17.8 & PEN-8/7 & 0.7 & \multicolumn{2}{|l|}{19.3} \\
\hline PEN-8/2 grey & 1.3 & 17.8 & PEN-8/4 white & 1.1 & \multicolumn{2}{|l|}{18.1} \\
\hline PEN-8/3 white & 1.7 & 17.7 & PEN-8/5 white & 1.2 & \multicolumn{2}{|l|}{17.1} \\
\hline PEN-8/3 grey & 1.5 & 17.6 & PEN-8/6 grey & 0.7 & \multicolumn{2}{|l|}{19.3} \\
\hline PEN-8/8 white & 1.1 & 18.2 & PEN-8/7 grey & 0.6 & \multicolumn{2}{|l|}{19.2} \\
\hline PEN-8/4 grey & 1.0 & 17.8 & & & & \\
\hline \multicolumn{2}{|c|}{ Calcites in quartz veins } & & \multicolumn{4}{|c|}{ Fluids in quartz veins } \\
\hline & $\delta^{13} \mathrm{C}$ & $\delta^{18} \mathrm{O}$ & & $\delta \mathrm{D}$ & & $\delta \mathrm{D}$ \\
\hline Q06-A13 & 1.3 & 17.5 & Q06-A8 & -63 & Q06-K25 & -70 \\
\hline Q06-A70 & -0.4 & 19.9 & Q06-A13 & -67 & Q06-K25B & -58 \\
\hline Q06-A89 & 0.5 & 21.3 & Q06-A70 & -43 & Q06-K31 & -52 \\
\hline Q06-K2 & -0.4 & 24.4 & Q06-A105 & -53 & Q06-B-R & -52 \\
\hline Q06-K19 & 1.6 & 23.2 & Q06-K2 & -47 & Q06-Ko & -79 \\
\hline Q06-K25 & -1.3 & 20.6 & Q06-K12 & -41 & Q06-St & -70 \\
\hline Q06-K25B & -1.3 & 20.0 & Q06-K19 & -64 & Q06-Zu & -40 \\
\hline Q06-St & 1.3 & 22.6 & & & & \\
\hline $\mathrm{Q} 06-\mathrm{Zu}$ & -0.8 & 19.6 & & & & \\
\hline
\end{tabular}

Fig. 5

$\mathrm{C}$ and $\mathrm{O}$ isotope compositions of calcites hosted by quartz veins (gray filled squares), matrix calcite of metasediments (circles) and ophicarbonates (filled circles) from the Penninic complex of the KõszegRechnitz series

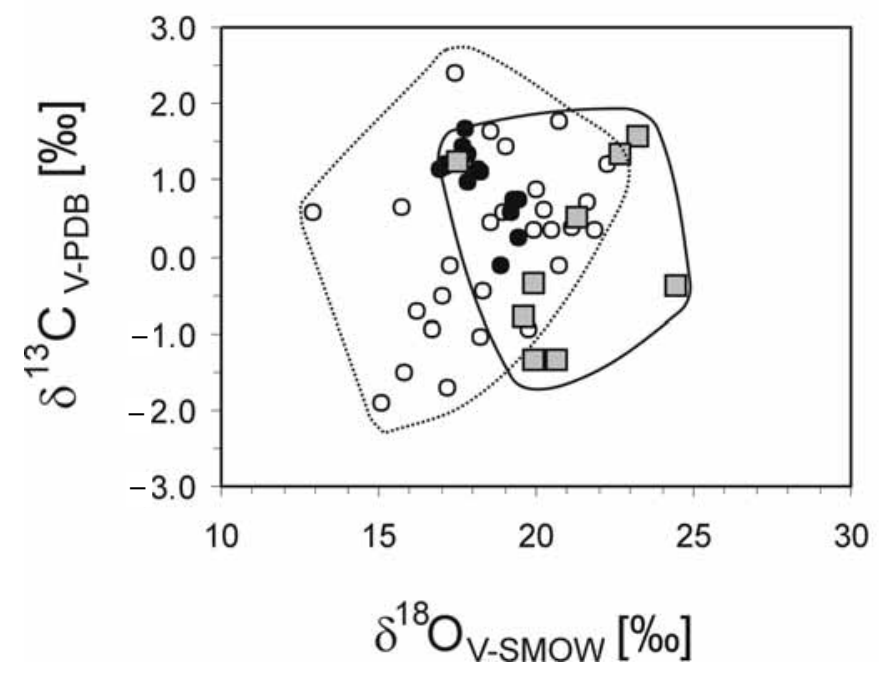

Central European Geology 50, 2007 
1993; Pozzorini and Früh-Green 1996). This carbon isotope range implies that the calcite may have been precipitated from hydrothermal solutions of seawater origin (containing dissolved carbonate, bicarbonate and $\mathrm{CO}_{2}$ with a total $\delta^{13} \mathrm{C}$ of about $0 \%$ ), or may have been derived from the mechanical mixing of sedimentary carbonate and silicate material and subsequent recrystallization during the metamorphic events. Although the $\delta^{18} \mathrm{O}$ values of the matrix calcite (17 to 19.5\%) are significantly more positive than those of the silicate rocks of the studied Penninic unit, they are far lower than normal marine limestone compositions (about 31\%o; Hoefs 1987). These values are likely related to higher precipitation temperatures of ophicarbonates relative to marine carbonate precipitation and/or indicate that the fluids were buffered to lower values of $\delta^{18} \mathrm{O}$ by interaction with the silicate hosts. Other studies on Alpine ophicarbonates obtained similar oxygen isotope compositions, the variations of which showed correlation with the degree of Alpine metamorphism (Weissert and Bernoulli 1984; Früh-Green et al. 1990), although Lemoine et al. (1983) attributed the $\delta^{18} \mathrm{O}$ values to the oceanic event.

The ophicalcite studied in the present paper would be in equilibrium with seawater at $80-100{ }^{\circ} \mathrm{C}$ (using the cal cite-water fractionation equation of Friedman and O'Neil 1977), which is a realistic temperature range for hydrothermal influences in the oceanic crust (Alt 2003). For further considerations on formation processes, isotopic fractionations between calcite and silicate minerals (chlorite, talc and blue amphibole) and their relationships with metamorphic temperatures can be investigated. The fractionations can be described by a general equation 1000 $\ln \alpha=A / T^{2}+B$, where $\alpha$ is the fractionation factor between calcite and the other minerals, $\mathrm{T}$ is temperature in $\mathrm{K}, \mathrm{A}$ and $\mathrm{B}$ are material-dependent constants. 1000 -In $\alpha \approx \delta^{18} \mathrm{O}$ (mineral) - $\delta^{18} \mathrm{O}$ (calcite). Thus, if the $\mathrm{O}$ isotope compositions of silicates are plotted relative to those of the calcite, the data would scatter along a line if the minerals equilibrated at the same temperature (e.g. Javoy et al. 1970). Figure 4 shows that the calcite-silicate fractionations do not yield a single straight line. The isotopic composition of the carbonates and silicates in these rocks has thus been controlled by different processes. The variations may be related to original unhomogeneities, different stages and hence temperatures of formation or last equilibration with fluids, and/or to late-stage isotope exchange. Looking at the minerals separately, however, reveals interesting relationships. Because the calcite represents the major $\mathrm{O}$-bearing phase in the ophicarbonates, during $\mathrm{O}$ isotope exchange between carbonates and silicates the $\delta^{18} \mathrm{O}$ values of silicate minerals would change, whereas that of the calcite would stay relatively constant. The calcite-chlorite fractionation obtained in this study would correspond to temperatures of about $300-700{ }^{\circ} \mathrm{C}$ (using the equation of Zheng 1993), reflecting both lower and higher metamorphic temperatures than those determined for the Kõszeg-Rechnitz unit (Koller 1985). In contrast, the calcitetalc fractionations yield temperatures from 80 to $250^{\circ} \mathrm{C}$ (Zheng 1993), with the lower limit being similar to calcite-seawater equilibrium temperatures (see 
above). Talc is thought to be rather insensitive to later $\mathrm{O}$ isotope exchange relative to chlorite or serpentine (Barnes et al. 2004). Thus, the isotopic compositions measured for talc would simply suggest lower temperatures of formation. The calcite-glaucophane fractionation would yield high temperatures (above 600-900 ${ }^{\circ} \mathrm{C}$; Zheng 1993), suggesting that the amphibole was either formed by episodic infiltration of ${ }^{18} \mathrm{O}$-enriched fluids or that it was formed at high temperatures. The high temperature obtained from one of the chlorite samples may be related to fine-grained overgrowth and, thus, incomplete separation from blue amphibole, or inheritance of amphibole compositions. The whole rock silicate fraction is dominated by chlorite, in accordance with the $\sim 300{ }^{\circ} \mathrm{C}$ temperature obtained from this sample. The $300{ }^{\circ} \mathrm{C}$ temperature is lower than the young Alpine metamorphic temperature and can be related to retrograde isotope exchange between chlorite, calcite and fluids upon cooling. The limited sample set precludes further clarification of the process. However, it is possible that talc hosted by the ophicalcite partially preserved a composition established during hydrothermal seafloor alteration, while chlorite shows al most complete resetting.

\section{$\mathrm{H}$ and $\mathrm{O}$ isotope compositions}

The most important processes that may modify the stable isotope composition of metamorphic rocks are devolatilization and late-stage alteration. Devolatilization would decrease the water content and - depending on the released fluid species $\left(\mathrm{H}_{2} \mathrm{O}\right.$ and/or $\left.\mathrm{CO}_{2}\right)$ - may change the $\delta^{18} \mathrm{O}$ values to higher or lower values (e.g. Valley 1986). In general, production and escape of $\mathrm{H}_{2}$ would strongly deplete the remaining rock in the light hydrogen isotope (producing a positive $\delta D$ shift, see Barnes et al. 2004), whereas dehydration would result in lower $\delta D$ values in the rock (Ripley et al. 1992; Valley 1986). The present data set does not show any systematic $\mathrm{H}_{2} \mathrm{O}-\delta \mathrm{D}$ variations. Two serpentinite samples yielded significantly lower $\delta \mathrm{D}$ values compared to the rest. This difference in $\delta \mathrm{D}$ is not, however, accompanied by a difference in $\delta^{18} \mathrm{O}$. This would suggest that the infiltrating fluid either had an isotopic composition al ready in equilibrium with the rock in terms of oxygen isotope composition, or the amount of fluid was too low to alter the oxygen isotope composition. Similar differences in $\delta D$ have been noted in other ophiolitic series, where they were related to exchange with meteoric water infiltrating during the late stage of metamorphism (e.g. Miller et al. 2001). A common influence producing the low $\delta D$ values in both of the samples is suggested by the $\delta \mathrm{D}-\delta^{18} \mathrm{O}$ relationship (Fig. 3). On the basis of Pozzorini and Früh-Green (1996), the low $\delta D$ values may be attributed to young Alpine metamorphic overprints. It is interesting to note that the low $\delta D$ values are rather subordinate in the Kõszeg-Rechnitz system and the sampled slickensides do not show any difference in their $\delta D$ values, suggesting that the infiltration of D-depleted fluids was of local importance only. 
The third outlier is an ophicalcite sample (sample PEN $-8 / 5$, with $\delta D=-46 \%$ ) that also shows lowered $\mathrm{H}_{2} \mathrm{O}$ content. As the $\mathrm{H}_{2} \mathrm{O}$ content of the silicate fraction is lower than in other ophicarbonates, $\mathrm{H}_{2}$ release cannot be excluded as a cause of the $\delta D$ elevation (see Barnes et al. 2004). However, as the sample is a whole rock silicate fraction, the $\mathrm{H}_{2} \mathrm{O}$ content decrease can also be related to the presence of anhydrous silicate minerals. In this case the elevated $\delta \mathrm{D}$ value is not related to $\mathrm{H}$-content decrease and can represent primary composition.

The average $\delta \mathrm{D}$ value of all the studied samples excluding the three outliers described above is $-64 \%$, with a standard deviation of $\pm 5 \%$, which is close to the analytical precision. This isotopic composition and the homogeneity could well be the result of either hydrothermal - oceanic or the subsequent Alpine metamorphic events. The ophicalcite, the formation of which is most probably related to oceanic hydrothermal influence and which has an average $\delta \mathrm{D}$ value of $-62 \pm 8 \%$, has compositions remarkably similar to the other samples. The average $\delta D$ value of talc (which is thought to have partially preserved the isotopic compositions related to the oceanic hydrothermal influence) is $-63 \%$, practically equal to the average of the ophicalcite-hosted silicates. These compositions fit the lower limit of the range of oceanic lizardite-chrysotile (Miller et al. 2001) that may indicate the influence of oceanic metamorphism of the ophiolite sequence. The $\mathrm{H}$ isotope compositions of fluids in equilibrium with the studied silicate minerals can be calculated using the inferred metamorphic temperatures (Koller 1985) and mineral-water $\mathrm{H}$ isotope fractionation relationships (Suzuoki and Epstein 1976; Graham et al. 1984; Graham et al. 1987). The cal culations yielded an average $\delta D$ value of $-41 \pm 15 \%$ o (see Fig. 6).

The $\delta^{18} \mathrm{O}$ values are at the high-end of the oceanic serpentinite compositions that usually do not exceed 10\%o (Miller et al. 2001). There are two possibilities to explain the ${ }^{18} \mathrm{O}$-enrichment: i) large-scale fluid infiltration from the sedimentary series of the same Penninic unit and ii) serpentinization in the ocean floor at low temperatures. In order to evaluate these possibilities, the compositions of the fluids emanating from the metasedimentary series should be known. The segregation quart veins that follow folding were formed during metamorphism and deformation and their fluid inclusions can therefore provide information on the compositions of fluids mobilized during the main metamorphic event. The $\mathrm{H}$ isotope compositions of inclusion fluids range from -79 to $-40 \%$, which is a range of values similar to those of fluids expected to be in equilibrium with the serpentinite. The $O$ isotope compositions of the fluids can be calculated from the $\delta^{18} \mathrm{O}$ values of vein-hosted calcites. The $C$ and $O$ isotope compositions of veinhosted and matrix calcites are very similar (Fig. 5), although the vein-hosted ones show a slight ${ }^{18} \mathrm{O}$-enrichment, probably related to limited retrograde $\mathrm{O}$ isotope exchange with the metamorphic fluids or lower temperatures of formation. The isotopic similarity between the vein-hosted calcite and the matrix carbonate supports the assumption that the veins were formed during the main 
Fig. 6

$\mathrm{H}$ and $\mathrm{O}$ isotope compositions of rocks (filled circles) and fluids in equilibrium with the studied ophiolitic rocks and minerals at $400{ }^{\circ} \mathrm{C}$ (open circles) and inclusion fluids of quartz veins (squares). Filled gray circle: fluid in equilibrium with low- $\delta D$ rock. The calculations were conducted using the fractionation equations of Suzuoki and Epstein (1976), Graham et al. (1984; 1987) and Zheng (1993). Isotope compositions of serpentinite samples are from Früh-Green et al. (2001)

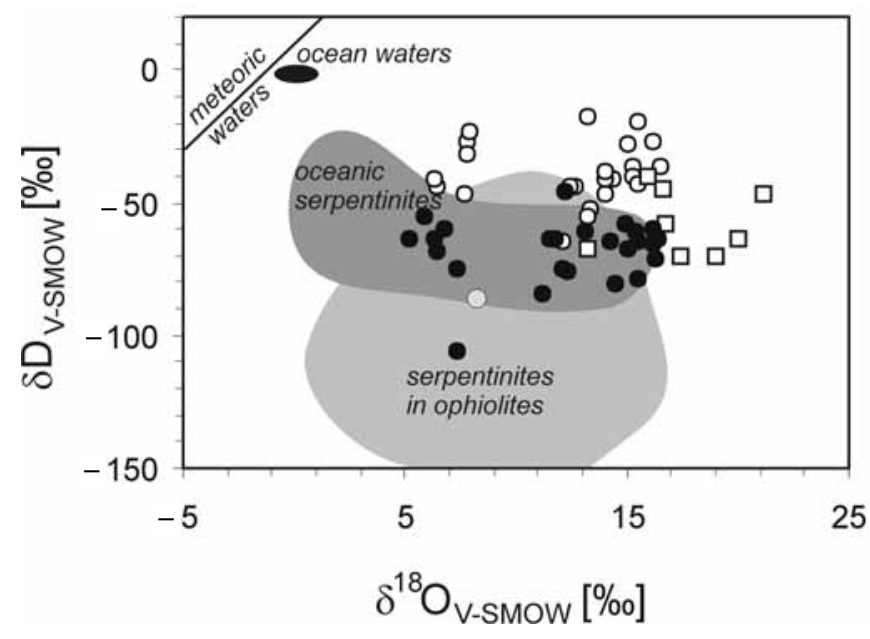

metamorphic event, but - due to the possibility of retrograde isotope exchange the calculated $\delta^{18} \mathrm{O}$ values are taken as upper limits.

The $\mathrm{H}$ and $\mathrm{O}$ isotope compositions of the fluids in equilibrium with serpentinite and silicate minerals of other rocks at $\sim 400{ }^{\circ} \mathrm{C}$ are plotted in Fig. 6 together with the data obtained from veins. The high- $\delta^{18} \mathrm{O}$ serpentinite would be in equilibrium with the metasediment-derived fluids, although its $\delta D$ range is extended to slightly higher values. Figure 6 shows the compositional fields of oceanic and ophiolite-hosted serpentinite (see Früh-Green et al. 2001 for literature compilation). The distribution of the isotopic compositions of fluids in Fig. 6 indicates that originally the serpentinite had isotopic compositions (with $\delta \mathrm{D}$ up to $-30 \%$ o) similar to the D-rich and ${ }^{18} \mathrm{O}$-depleted part of the oceanic serpentinite that was partially overprinted by interaction with fluids released from the metasedimentary series during the young alpine metamorphism, causing negative $\delta D$ and positive $\delta^{18} \mathrm{O}$ shifts. The assumed original Denrichment can be explained by the oceanic hydrothermal event. Meteoric water infiltration was limited and can be observed in some serpentinite samples (marked by a gray filled circle).

The close-to-magmatic $\delta^{18} \mathrm{O}$ values ( 6\%) preserved in some serpentinite and associated rocks, and the non-equilibrium fractionations between silicates and carbonates observed in ophicarbonates, suggest that these rocks reflect oceanic hydrothermal processes. The $80-130{ }^{\circ} \mathrm{C}$ temperature range inferred from seawater-rock exchange implies that serpentinization occurred close to the seawater-oceanic crust interface. Exhumation by low-angle detachment faults assumed for the Penninic ocean (Lagabrielle and Lemoine 1997) can explain the sudden cooling and this low-temperature serpentinization process. 


\section{Subduction and devolatilization}

Subduction of the serpentinized ophiolite complex may release volatiles through direct degassing and/or separation of a fluid-rich melt. The fluids released may cause metasomatism in the overlying rocks and/or mantle wedge. Degassing processes and loss of volatiles would also change the isotopic composition of the remaining fraction of the rocks. Scambelluri et al. (1995) showed that serpentine minerals can survive subduction and can be preserved up to the eclogite facies. Thus, subduction of serpentinite can carry large amount of volatile-rich material into the mantle. Melting and mixing of the D- and ${ }^{18} \mathrm{O}$ enriched crust with the mantle material can substantially modify the hydrogen as well as the oxygen isotope composition of the upper mantle. This process may also lead to an increase the $\mathrm{Fe}^{3+} / \mathrm{Fe}^{2+}$ ratio in the metasomatized mantle.

Degassing can begin at temperatures above $300{ }^{\circ} \mathrm{C}$, temperatures at which mineral-water hydrogen isotope fractionations are negative (Suzuoki and Epstein 1976), i.e. the water-rich fluid released is enriched in deuterium. The hydrogen isotope fractionations are not temperature-sensitive; thus, the calculated water compositions do not vary in the temperature range of $300-500{ }^{\circ} \mathrm{C}$. The $\delta \mathrm{D}$ (water) values calculated from the mineral data range from -86 to $-18 \%$, with an average of $-41 \%$ o. For oxygen, the isotope fractionations are slightly positive (Zheng 1993). The oxygen isotope composition of water in equilibrium with the studied minerals ranges from 6 to $15.5 \%$ ond from 6.8 to $17.1 \%$ at temperatures of 300 and $500{ }^{\circ} \mathrm{C}$, respectively (using the fractionation equations of Zheng 1993). Release of fluids with these isotopic compositions would significantly alter the hydrogen isotope composition of the mantle. Taking the amount of oxygen in the fluid and in the mantle wedge into account, it would, however, require very large amounts of fluids to change the oxygen isotope composition of the mantle. The Kõszeg-Rechnitz ophiolite series was oxidized during metamorphism (Koller 1985) with an average $\mathrm{Fe}^{3+} / \mathrm{Fe}^{2+}$ ratio of about 0.5 (calculated from the data presented by Koller 1985). The fluid may not bring significant amount of Fe; however, metasomatism by this fluid would also produce slight oxidation in the mantle material.

Demény et al. (2005) investigated hydrogen isotope compositions and $\mathrm{Fe}^{3+}$ contents in mantle-derived amphiboles of the Plio-Pleistocene alkaline basalts of the Carpathian Basin. The studied amphiboles showed signs of degassing-related $\mathrm{H}$ isotope fractionations and oxidation with starting compositions of $\delta \mathrm{D}$ about $-40 \%$ ond $\mathrm{Fe}^{3+} / \mathrm{Fe}_{\text {total }}$ ratio of $\sim 0.3$. These values indicate oxidation and Denrichment relative to unaltered mantle $\left(\mathrm{Fe}^{3+} / \mathrm{Fe}_{\text {total }}\right.$ of $\mathrm{MORB} \sim 0.05$, Christie et al. 1986; $\delta \mathrm{D} \sim-70 \pm 10 \%$ o, Kyser 1986). The primary $\mathrm{H}$ isotope composition inferred for the amphiboles is in striking agreement with the $\delta D$ values obtained for modeling degassing of the Penninic oceanic crust. Thus, these observations support the idea of Szabó et al. (1996), Bali et al. (2002) and Demény et al. (2004), namely that the mantle beneath the Pannonian region was metasomatized by fluids emanating from subducted oceanic crust material. 
Assumptions on the origin of leucophyllite

On the basis of geochemical and stable isotope data, Demény et al. (1997) have suggested that the formation of the Sopron leucophyllite occurrences was induced by metasomatic influence of $\mathrm{D}$-enriched and $\mathrm{Mg}$-rich fluids released from serpentinite. The tectonic relationships and proximity to the serpentinite support the concept that these rocks are also the most likely candidates for the fluids responsible for the isotopic composition of the leucophyllite. In order to explain the D-enrichment in the leucophyllite (with $\delta D$ values up to $-30 \%$ ), a fluid composition of about $0 \%$ (and a source rock composition of about $-30 \%$ ) is required. The present data set obtained for the Kõszeg-Rechnitz series does not contain such high $\delta D$ values. The reason for the missing $D$-enrichment in the Penninic rocks may be related to: 1 . the primary absence of high- $\delta D$ rocks, 2 . incomplete sampling, 3. equilibration during late metamorphic events, or 4. preferential degassing of D-enriched rocks during beginning subduction and metamorphism. The results of the present study suggest that high $\delta D$ values were indeed produced by the oceanic metamorphism in the Penninic ophiolites of the Kõszeg-Rechnitz series, but the young Alpine metamorphic event almost completely overprinted them. The fact that the age of the HP/LT Eoal pine metamorphic event ( $<60 \mathrm{Ma}$, Hoinkes et al. 1999) does not fit the age of the leucophyllite formation (80 Ma, Demény and Nagy 2002; Nagy et al. 2002), has been used as an argument against the metasomatic influence by fluids released from the Penninic ophiolites. However, an early burial of the serpentinite by the first nappe overthrusting may have released pore fluids and structural water of silicate minerals rich in $\mathrm{D}$ and $\mathrm{Mg}$, as an overture to the subduction process later leading to the HP/LT metamorphism. Nevertheless, direct evidence of high $\delta D$ values in the Penninic unit was not found in the course of the present study. Further studies aiming at the earliest degassing processes of the Penninic system may yield important information on the assumed metasomatic influence.

\section{Conclusions}

Stable $\mathrm{H}, \mathrm{C}$ and $\mathrm{O}$ isotope compositions were determined for the rocks of the ophiolite series of the Kõszeg-Rechnitz series. The $\mathrm{H}$ isotope compositions are rather homogeneous with only some outliers showing deuterium depletion. The low $\delta D$ values indicate meteoric water infiltration, but their restricted occurrence suggests that the interaction with meteoric waters was limited. The $O$ isotope compositions of the studied ophiolitic rocks (serpentinite, gabbro, rodingite, silicates in ophicarbonate rocks) show a large scatter from close-to-magmatic values to significant ${ }^{18} \mathrm{O}$-enrichment. Stable isotope compositions of fluids mobilized during the metamorphism of the sedimentary rocks of the Penninic unit were also determined in order to investigate possible interactions with the ophiolitic series. The data indicate that interaction between the sediment-derived fluids and the ophiolitic rocks may have indeed taken place, but the D- 
enrichment related to oceanic hydrothermal metamorphism has been preserved, at least in some rocks.

The isotope compositions determined in this study support the contention that the fluids released from the ophiolite sequence during subduction may be responsible for the deuterium enrichment in the Carpathian-Pannonian mantle shown by Demény et al. (2004). The very high $\delta D$ values required for the metasomatic formation of the Sopron leucophyllite as suggested by Demény et al. (1997) were not found in the Penninic ophiolites.

\section{Acknowledgements}

The work presented in this study was financially supported by the Hungarian National Research Fund (OTKA T 43098). Financial support to A.D. was kindly provided by the Fondation Herbette, allowing for a threemonth stay at the University of Lausanne where analyses of silicate minerals were conducted. Formal reviews by Gy. Lelkes-Felvári and A. Embey-Isztin helped improve the paper and are gratefully acknowledged.

\section{References}

Alt, J.C. 2003: Stable isotopic composition of upper oceanic crust formed at a fast spreading ridge, ODP Site 801. - Geochemistry Geophysics Geosystems, 4, Art. No. 8908.

Bali, E., Cs. Szabó, O. Vaselli, K. Török 2002: Significance of silicate melt pockets in upper mantle xenoliths from the Bakony-Balaton Highland Volcanic Field, Western Hungary. - Lithos, 61, pp. 79-102.

Barbieri, M., U. Masi, L. Tolomeo 1979: Stable isotope evidence for a marine origin of ophicalcites from the North-Central Apennines (Italy). - Marine Geology, 30, pp. 193-204.

Barnes, J.D., J. Selverstone, Z.D. Sharp 2004: Interactions between serpentinite devolatilization, metasomatism and strike-slip strain localization during deep-crustal shearing in the Eastern Alps. - Journal of Metamorphic Geology, 22/4, pp. 283-300.

Christie, D.M., I.S.E. Carmichael, C.H. Langmuir 1986: Oxidation states of mid-ocean ridge basalt glasses. - Earth Planet. Sci. Lett., 79, pp. 397-411.

Demény, A. 1990: Ásványtani, geokémiai és stabilizotóp-vizsgálatok a hazai Penninikum kõzeteiben: A Kõszeg-rohonci-sorozat és a Tauern-ablak összevetése (Mineralogical, geochemical and stable isotope investigations in the Penninic rocks of Hungary: A comparison of the Kõszeg-Rechnitz Series and the Tauern Window). - Dr. univ. thesis, Eötvös Loránd University, Budapest, 100 p. (In Hungarian.)

Demény, A., G. Nagy 2002: Comments on the paper "Multiple fluid migration events in the Sopron Gneisses during the Alpine high-pressure metamorphism, as recorded by bulk-rock and mineral chemistry and fluid inclusions" by Kálmán Török (N.Jb. Miner. Abh., 2001, vol. 177, 1-36). - N.Jb. Miner. Abh., 178, pp. 93-98.

Demény, A., Z.D. Sharp, H.-R. Pfeifer 1997: Mg-metasomatism and formation conditions of Mgchlorite-muscovite-quartzphyllites (leucophyllites) of the Eastern Alps (W. Hungary) and their relations to Alpine whiteschists. - Contributions to Mineralogy and Petrology, 128, pp. 247-260.

Demény, A., T.W. Vennemann, E. Hegner, G. Nagy, J.A. Milton, A., Embey-Isztin, Z. Homonnay 2004: Trace element and $\mathrm{C}-\mathrm{O}-\mathrm{Sr}-\mathrm{Nd}$ isotope evidence for subduction-related carbonate-silicate melts in mantle xenoliths (Pannonian Basin, Hungary). - Lithos, 75, pp. 89-113. 
Demény, A., T.W. Vennemann, Z. Homonnay, A. Milton, A. Embey-Isztin, G. Nagy 2005: Origin of amphibole megacrysts in the Plio-Pleistocene basalts of the Carpathian-Pannonian Region. Geologica Carpathica, 56/2, pp. 179-189.

Driesner, T. 1993: Aspects of petrological, structural and stable isotope geochemical evolution of ophicarbonate breccias from ocean floor to subduction and uplift: An example from Chatillon, Middle Aosta Valley, Italian Alps. - Schweiz. Mineral. Petrogr. Mitt., 73, pp. 69-84.

Dudko, A., M.T. Younes 1990: Alpine plastic deformation in the Kõszeg Mountains (Hungary). Földtani Közlöny, 120, pp. 69-82.

Dunkl, I., A. Demény 1997: Exhumation of the Rechnitz Window at the border of Eastern Alps and Pannonian basin during N eogene extension. - Tectonophysics, 272, pp. 197-211.

Friedman, I., J.R. O'N eil 1977: Compilation of stable isotope fractionation factors of geochemical interest. - In: Data of Geochemistry 6th, Geol. Surv. Prof. Paper 440-KK., p. 12.

Früh-Green, G.L., H. Weissert, D. Bernoulli 1990: A multiple fluid history recorded in Alpine ophiolites. - J. Geol. Soc. London, 147, pp. 959-970.

Früh-Green, G., D.S. Kelley, J.A. Karson, D.K. Blackman, C. Boschi, B.E, John, T. Schroeder, D.K. Ross and MARVEL cruise participants, 2001: Hydrothermal alteration, serpentinization and carbonate precipitation at the Lost City vent field (30N MAR). - Eos, Trans. Am. Geophys. Union, 82, pp. F1101.

Graham, C.M., R.S. Harmon, S.M.F. Sheppard 1984: Experimental hydrogen isotope studies: Hydrogen isotope exchange between amphibole and water. - Amer. Mineral., 69, pp. 128-138.

Graham, C.M., J.A. Viglino, R.S. Harmon 1987: Experimental study of hydrogen-isotope exchange between aluminous chlorite and water and of hydrogen diffusion in chlorite. - Amer. Mineral., 72, pp. 566-579.

Hoefs, J. 1987: Stable Isotope Geochemistry. Third edition - Springer-Verlag, Berlin, 241 p.

Hoinkes, G., F. Koller, G. Rantitsch, E. Dachs, V. Höck, F. Neubauer, R. Schuster 1999: Alpine metamorphism of the Eastern Alps. - Schweiz. Mineral. Petrogr. Mitt., 79, pp. 155-181.

Javoy, M., S. Fourcade, C.J. Allegre 1970: Graphical method for examination of ${ }^{18} \mathrm{O} /{ }^{16} \mathrm{O}$ fractionations in silicate rocks. - Earth and Planetary Science Letters, 10, pp. 12-16.

Kasemann, S., A. Meixner, A. Rocholl, T. Vennemann, A. Schmitt, M. Wiedenbeck 2001: Boron and oxygen isotope composition of certified reference materials NIST SRM 610/612, and reference materials JB-2G and JR-2G. - Geostandards Newsletter, 25, pp. 405-416.

Koller, F., A. Pahr 1980: The Penninic ophiolites on the eastern end of the Alps. - Ofioliti, 5, pp. 65-72.

Koller, F. 1985: Petrologie und Geochemie der O phiolite des Penninikums am Alpenostrand. Jahrbuch der Geologischen Bundesanstalt, Wien, 128, pp. 83-150.

Kubovics, I. 1983: Petrological characteristics and genetic features of the crossitite from Western Hungary. - Földtani Közlöny, 113, pp. 207-224.

Kyser, T.K. 1986: Stable isotope variations in the mantle. - In: Valley, J.W., H.P. Jr. Taylor, J.R. O'N eil (Eds): Stable isotopes in high temperature geological processes. - Reviews in Mineralogy, Mineralogical Society of America, 16, pp. 141-164.

Lagabrielle, Y., M. Lemoine 1997: Alpine, Corsican and Apennine ophiolites: the slow-spreading ridge model. Comptes Rendus de I'Academie des Sciences Series IIA - Earth and Planetary Science, 325, pp. 909-920.

Lelkes-Felvári, Gy. 1982: A contribution to the knowledge of the Alpine metamorphism in the Kõszeg-Vashegy area (Western Hungary). - Neues Jahrbuch Geol. Paläont. Mh., 5, pp. 297-305

Lemoine, M., M. Bourbon, P-Ch. de Graciansky, R. Létolle 1983: Isotopes du carbone et de l'oxygéne de calcaires associés a des ophiolites (Alpes Occidentales, Corse, Apennin): indices possibles d'un hydrothermalisme océanique téthysien. - Revue de Géologie Dynamique et de Géographie Physique, 24, pp. 305-314.

Mattey, D., D. Lowry, C. Macpherson 1994: Oxygen isotope composition of mantle peridotite. Earth Planet. Sci. Lett., 128, pp. 231-241. 
46 A. D emény et al.

Meisel, Th., F. Melcher, P. Tomascak, Ch. Dingeldey, F. Koller 1997: Re-Os isotopes in orogenic peridotite massifs in the Eastern Alps, Austria. - Chemical Geology, 143, pp. 217-229.

Melcher, F., T. Meisel, J. Puhl, F. Koller 2002: Petrogenesis and geotectonic setting of ultramafic rocks in the Eastern Alps: constraints from geochemistry. - Lithos, 65, pp. 69-112.

Miller, J.A., I. Cartwright, I.S. Buick, A.C. Barnicoat 2001: An O-isotope profile through the HP-LT Corsican ophiolite, France and its implications for fluid flow during subduction. - Chemical Geology, 178, pp. 43-69.

Nagy, G., E. Draganits, A. Demény, Gy. Pantó, P. Árkai. 2002: Genesis and transformations of monazite, florencite and rhabdophane during mediumgrade metamorphism: Examples from the Sopron Hills, Eastern Alps. - Chemical Geology, 191, pp. 25-46.

Neubauer, F., R.D. Dallmeyer, I. Dunkl, F. Ebner, H. Fritz, R. Handler, B. Hubmann, F. Koller, W. Müller, P. Peindl, E. Wallbrecher, W. Kiesl, A. Takasu, H.H. Weinke 1992: Excursion to the Eastern Central Alps: descriptions of stops. - In: Neubauer, F. (Ed.): Geological Evolution of the Internal Eastern Alps and Carpathians and of the Pannonian Basin (ALCAPA). Field Guide, Graz, pp. 201-245.

Pozzorini, D., G.L. Früh-Green 1996: Stable isotope systematics of the Ventina O phicarbonate Zone, Bergell contact aureole. - Schweiz. Mineral. Petrogr. Mitt., 76, pp. 549-564.

Ratschbacher, L., J.H. Behrmann, A. Pahr 1990: Penninic windows at the eastern end the Alps and their relation to the intra-Carpathian basins. - Tectonophysics, 172, pp. 91-105.

Ripley, E.M., B.K. Butler, N.I. Taib 1992: Effects of devolatilization on the hydrogen isotopic composition of pelitic rocks in the contact aureole. - Chem. Geol. (Isot. Geosci. Sect.), 102, pp. 185-197.

Rumble, D., T.C. Hoering 1994: Analysis of oxygen and sulfur isotope ratios in oxide and sulfide minerals by spot heating with a carbon dioxide laser in a fluorine atmosphere. - Accounts of Chemical Research, 27, pp. 237-241.

Scambelluri, M., O. Müntener, J. Hermann, G.B. Piccarrdo, V. Trommsdorff 1995: Subduction of water into the mantle: History of an Alpine peridotite. - Geology, 23, pp. 459-462.

Sharp, Z.D., V. Atudorei, T. Durakiewicz 2001: A rapid method for determination of hydrogen and oxygen isotope ratios from water and solid hydrous substances. - Chem. Geol., 178, pp. 197-210.

Spötl, C., T. Vennemann 2003: Continuous-flow isotope ratio mass spectrometric analysis of carbonate minerals. - Rapid Communications in Mass Spectrometry, 17, pp. 1004-1006.

Suzuoki, T., S. Epstein 1976: Hydrogen isotope fractionation between $\mathrm{OH}$-bearing minerals and water. - Geochim. Cosmochim. Acta, 40, pp. 1229-1240.

Szabó, Cs., R.J. Bodnar, A.V. Sobolev 1996: Metasomatism associated with subduction-related, volatile-rich silicate melt in the upper mantle beneath the Nógrád-Gömör Volcanic field, Northern Hungary / Southern Slovakia: Evidence from silicate melt inclusions. - Eur. J. Mineral., 8, pp. 881-899.

Tari, G., A.W. Bally, 1990: Metamorphic core complexes at the boundary of the Eastern Alps and the Pannonian basin. - Geological Society of America, Abstract with Programs, pp. 97-98.

Valley, J. W. 1986: Stable isotope geochemistry of metamorphic rocks.- In: Valley, J.W., Jr. H. P. Taylor, J.R. O'Neil (Eds): Stable isotopes in high temperature geological processes. - Reviews in Mineralogy, 16, pp. 445-489.

Valley, J.W., N. Kitchen, M.J. Kohn, C.R. Niendorf, M.J. Spicuzza 1995: UWG-2, a garnet standard for oxygen isotope ratios: Strategies for high precision and accuracy with laser heating. Geochimica et Cosmochimica Acta, 59, pp. 5523-5531.

Weissert, H., D. Bernoulli 1984: Oxygen isotope composition of calcite in Alpine ophicarbonates: a hydrothermal or Alpine metamorphic signal? - Eclogae Geol. Helv., 77, pp. 29-43.

Wiedemann, R., M.T. Younes 1990: Studien zur Gefügeentwicklung (Quarzkorngefügeanalyse) im Penninikum von Rechnitz/Kõszeg (Österreich/Ungarn). - Jahrbuch der Geologischen Bundesanstalt, Wien, 133, pp. 385-394.

Zheng, Y.-F. 1993: Calculation of oxygen isotope fractionation in hydroxil-bearing silicates. - Earth Planet. Sci. Lett., 120, pp. 247-263. 